\title{
The Influence of Electronic Word of Mouth Toward Destination Trust and Travel Intention on Sirandah Island in Padang City
}

\author{
Okki Trinanda ${ }^{1}$, Putra Deta Mutaqin ${ }^{2}$ \\ Universitas Negeri Padang \\ okki.trinanda@fe.unp.ac.id
}

\begin{abstract}
This research aims to analyze: (1) The influence of electronic word of mouth toward travel intention on Sirandah Island in Padang City (2) The influence of electronic word of mouth toward destination trust on Sirandah Island in Padang City (3) The influence of destination trust toward travel intention on Sirandah Island in Padang City. The type of this research is causative research. The population on this research is all Padang city society who have read online reviews of Sirandah Island in the internet and have never visited Sirandah Island whose numbers are unknwon. Data were collected through questionnaires and 170 questionnaires were analyzed by performing structural equation modeling (SEM) in SmartPLS 3.2.7. The result of this research show that (1) electronic word of mouth has a significant influenced on travel intention at Sirandah Island in Padang City (2) electronic word of mouth has a significant influenced on destination trust at Sirandah Island in Padang City (3) destination trust has a significant influenced on travel intention at Sirandah Island in Padang City.
\end{abstract}

Keyword: Electronic Word of Mouth, Destination Trust, Travel Intention

\section{Introduction}

One of the impacts of tourism as a business is to influence the economy of the surrounding community. The high number of tourist visits has a positive impact on the economy of the community around tourist destinations (Vada, Prentice, \& Hsiao, 2018). For this reason, lately many countries in the world are competing to fix their tourism sector and invite as many tourists as possible to visit their countries to enjoy tourist destinations in various promotional ways that can attract interest in visiting their country.

One country that is currently very aggressively conducting tourism promotions to attract tourists to their country is Indonesia (Wardi, Abror, \& Trinanda, 2018a). Of the many Provinces in Indonesia, one of the provinces that has the potential to develop its tourism sector is the Province of West Sumatra. West Sumatra Province is famous for its natural beauty and there is also a legacy of its historical wealth that is different from other provinces in Indonesia (Wardi, Abror, \& Trinanda, 2017). Seen from tourist visits to the Province of West Sumatra each year has increased. These conditions indicate that the potential for tourism in the province of West Sumatra is one of the national tourist destinations.

\footnotetext{
${ }^{1}$ Korespondensi: Okki Trinanda. Universitas Negeri Padang. Jl. Prof. Dr. Hamka, Air Tawar Padang. okki.trinanda@fe.unp.ac.id

${ }^{2}$ Korespondensi: Putra Deta Mutaqin. Universitas Negeri Padang. Jl. Prof. Dr. Hamka, Air Tawar Padang. putradetamutaqin@gmail.com
} 
Table 1. Number of Tourist Visits to the City of Padang (2013-2016)

\begin{tabular}{|l|l|l|}
\hline Year & $\begin{array}{l}\text { Number of } \\
\text { Travelers }\end{array}$ & Growth \\
\hline 2013 & 6.310 .073 & - \\
\hline 2014 & 6.661 .849 & $5,28 \%$ \\
\hline 2015 & 7.022 .433 & $5,13 \%$ \\
\hline 2016 & 7.392 .968 & $5,01 \%$ \\
\hline
\end{tabular}

Source: Badan Pusat Statistik Provinsi Sumatera Barat

From Table 1 above it can be concluded that the number of tourist visits to West Sumatra Province has increased quite positively but has experienced a decline in growth each year. The highest growth is in 2014 at 5.28\%. In addition, the Province of West Sumatra has many excellent tourism areas that are interesting to visit, one of which is the City of Padang.

The effectiveness and efficiency of promotional communication requires the right strategy so that promotion can be achieved as intended. One of the promotion strategies can be applied in the field of tourism. The strategy in the field of tourism is important because regions that have tourism potential can have opportunities to improve the existence of the area. In addition, the strategy in the field of tourism is carried out in order to achieve the goals set by the Padang City Culture and Tourism Office. Tourism itself is an activity that is also dynamic and involves many people.

In the current era of globalization, the tourism sector is one of the drivers of the economy of a country(Vada et al., 2018). In the context of tourism, it takes two processes that must be managed in the exchange of information, information about a destination and the role of the media. The level of success of tourism promotion communication in the destination context is conveying a message about a tourism destination to the right prospective customers. The development of the tourism sector always needs to be developed and improved because if viewed from the socio-economic aspect it can increase people's income, expand employment opportunities, increase government revenues, increase foreign exchange earnings and increase national entrepreneurship.

Table 2. Number of Tourist Visits to the City of Padang (2013-2016)

\begin{tabular}{|l|l|l|l|}
\hline Year & Domestic & International & Total \\
\hline 2013 & 3.001 .306 & 53.057 & 3.054 .363 \\
\hline 2014 & 3.199 .392 & 54.967 & 3.254 .359 \\
\hline 2015 & 3.298 .454 & 57.318 & 3.355 .772 \\
\hline 2016 & 3.632 .820 & 58.903 & 3.691 .723 \\
\hline
\end{tabular}

Source: Dinas Kebudayaan dan Parawisata Kota Padang

From Table 2 above, it can be seen that the number of tourist visits to the city of Padang has increased from year to year or it can be interpreted that the number of visitors to the tourist attraction of Padang City has increased from year to year. One tourist attraction that is interested in being visited by tourists to the city of Padang is Sirandah Island. Sirandah Island is one of the marine tourism destinations in the city of Padang which is currently the belle of marine tourism destinations by local tourists in the city of Padang for those who can travel through the villages of Sungai Pisang and Bunguih Teluk Kabuang. Sirandah Island is famous for its beautiful sea, coral reefs, and cleanliness and also has beautiful scenery. The tourists can do various activities, such as taking pictures, underwater photos, sunbathing, diving, free diving and others.

The results of observations conducted by researchers at the tourist attraction of Sirandah Island on April 30, 2018. Penelti received information that Sirandah Island was contracted by 
Pujo Hartoyo (53 years) to the village of Teluk Kabung Selatan (Sungai Pisang). Based on interviews with Pujo Hartoyo (manager of Sirandah Island tourist attraction), tourist visits to Sirandah Island from fishermen carrying tourists on the Pisang River in Bunguih Teluk Kabuang, shipping fishermen can bring around 50 tourists per day, such as weekends, long holidays weekends, while for large holidays such as Eid holidays, New Year, Chinese New Year, long school holidays, fishermen can transport tourists around 100 tourists per day off, while for fishermen who carry tourists in Bunguih, by boat can reach 40 tourists every day. He also added that the number of tourist visits to the tourist attraction of Sirandah Island annually is around 60,000 tourists. However, he said that he did not have an accurate database of the number of visitors to the Sirandah Island tourist attraction because neat data collection had not been conducted

Based on the results of the observations above, the number of visitors to Sirandah Island attractions if we compare the data on the number of tourist visits to the city of Padang, found that the number of tourist visits to the tourist attraction of Sirandah Island still has a small number of tourist visits compared to the number of tourist visits to Padang. Where if present, the number of tourist visits to the tourist attraction of Sirandah Island is only around $1.7 \%$ of the number of tourist visits to the City of Padang in 2016. Where this indicates that Sirandah Island is one of the tourist attractions in the city of Padang which is still less attractive for tourists.

Based on the facts above, it is necessary to take concrete actions to overcome these problems, especially in finding ways to provide more value to visitors who are interested in their interest in visiting the tourist attractions of Sirandah Island. Tourists who have visited and have traveled, then they certainly want to share their love with others, whether they know or not. They tell about what they get and what they get while traveling or traveling in the tourist attraction. Tourists who have visited these attractions tell stories and offer recommendations to their friends to the places they have visited.

As for the factors that can influence someone's interest in visiting, one of them is caused by a recommendation from friends or relatives who say that the tourist object is right to be visited as a vacation time filler such as the posts about attractions on social media, blogs, websites, etc. otherwise or it can be said that there are reviews or reviews from tourists who have visited Sirandah Island through the internet. This includes WOM (word of mouth) based on technology, commonly referred to as EWOM (electronic word of mouth). Electronic word of mouth itself can be interpreted as a positive or negative statement made by a potential customer, actual, or excustomer about a product or company that is available to many people and institutions through the internet (Wardi et al., 2018a). So it can be said that visiting interests can be influenced by friends or relatives who provide verbal recommendations and electronic based recommendations (Manes \& Tchetchik, 2018).

Electronic word of mouth is one of the important things in marketing. By using EWOM the company can benefit from low cost and high impact, especially for products with high levels of competition such as the tourism business. In line with the increasingly expressiveness of social media, consumers will increasingly be able to influence other consumers with their opinions and experiences. EWOM is a container or a place that is very important for consumers to give their opinions and are considered more effective than word of mouth (WOM) because of their wider level of accessibility and reach. Marketers need to pay attention to EWOM because generally someone will listen to opinions from close relatives and friends, or other people they consider experts (Hussain et al., 2018).

With the growing development of internet technology, there is also the convenience of tourists in searching for information about tourist destinations and conducting online transactions. This is evidenced by the results of a survey conducted by Nielsen (Global Connected Commerce, 2016) which states that $63 \%$ of internet users around the world conduct information searches on a 
tourist attraction. Based on the results of the Nielsen survey, the author conducted a pre-survey using the hashtag (hashtag) in the form of the 4 largest tourist objects in West Sumatra on the search menu in the Instagram social media application on May 12, 2018 at 17:00 WIB. Where the number of hashtags indicates that how many of these attractions are discussed / touched on by someone on the Instagram social media. Here is the data about the number of tourist hashtags on Instagram social media:

Table 3. Number of Hastags of West Sumatra Tourism Objects on Instagram

Source: Instagram (2018)

\begin{tabular}{|l|l|}
\hline Objek Wisata & $\begin{array}{l}\text { Jumlah Hastag } \\
\text { (kali) }\end{array}$ \\
\hline $\begin{array}{l}\text { Jam Gadang } \\
\text { \#jamgadang; \#jamgadangbukittinggi; } \\
\text { \#jamgadangbkt }\end{array}$ & 89.059 \\
\hline $\begin{array}{l}\text { Puncak Lawang } \\
\text { \#puncaklawang; \#lawangpark; } \\
\text { \#puncaklawangpark; }\end{array}$ & 45.770 \\
\hline $\begin{array}{l}\text { Danau Singkarak } \\
\text { \#danausingkarak; \#singkarak; \#singkaraklake }\end{array}$ & 35.226 \\
\hline $\begin{array}{l}\text { Pulau Sirandah } \\
\text { \#sirandahisland; \#pulausirandah; \#sirandah }\end{array}$ & 22.089 \\
\hline
\end{tabular}

Based on Table 3 above, it can be seen that the tourist attraction of Sirandah Island compared to other Tourism Objects in West Sumatra is still not discussed by Instagram social media users, with the number of hashtags is only 22,089 times. While other attractions, such as Jam Gadang, have the highest number of hashtags as many as 89,059 times, Puncak Lawang as many as 45,770 times, and Lake Singkarak as many as 35,226 times. Based on these data, it can be concluded that EWOM marketing communications in Sirandah Island are still under discussion by netizens (internet users).

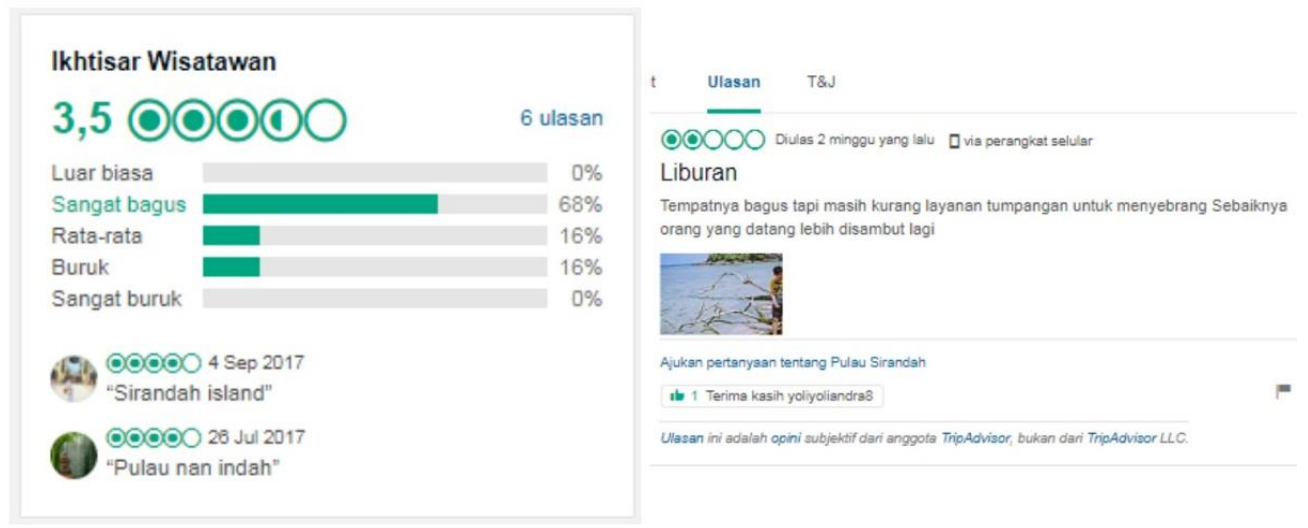

Figure 1. Tourist Overview of Sirandah Island on Website TripAdvisor.com

Source: TripAdvisor (2018)

Based on Figure 1 above, it can be seen several reviews of tourists who have visited the tourist attraction of Sirandah Island. It is seen that tourists using the TripAdvisor website provide reviews for a total of 3 stars as well as comments and criticisms about the tourist attraction of Sirandah Island. These reviews will have an impact on the desire to visit tourists.

EWOM is functioned as a way of marketing so that visitors can immediately understand and be clear about a tourism product. Furthermore, visitors will also go through alternative evaluation 
stages. Here visitors will choose the destination they trust. Statements in EWOM whether they are positive or negative can affect trust in a person's destination and interest in visiting (Abubakar \& Ilkan, 2016). The results of his research state that; EWOM has a positive effect on destination trust and visiting interests and destination trust has a positive effect on visiting interests. Barnes (2003) argues that trust is the belief that someone will find what is desired in an exchange partner. Trust involves a person's willingness to behave because of the belief that his partner will give what he expects and an expectation that is generally owned by someone that words, promises or statements of others can be trusted. A person's willingness encourages the creation of an interest in visiting. Visitors will choose destinations that contain attributes that they believe are relevant to what they need. These attributes can be formed due to the influence of EWOM. This form of EWOM has become an important factor in shaping customer behavior. Through reviews from other visitors in sharing a platform review can affect someone's interest in visiting (Jalilvand, N. Samiei, Dini, \& Manzari, 2012). Based on the description above, the authors are interested in conducting research with the title "The Influence of Electronic Word of Mouth toward Destination Trust and Intention to Visit Sirandah Island in Padang City". This research aims to find out: (1) The influence of electronic word of mouth toward travel intention on Sirandah Island in Padang City (2) The influence of electronic word of mouth toward destination trust on Sirandah Island in Padang City (3) The influence of destination trust toward travel intention on Sirandah Island in Padang City.

\section{Method}

The type of research will be conducted is causative research. Thus research explain and illustrates the relationship between the electronic word of mouth (endogenous variables) toward destination trust and travel intention (exogenous variables) (Evanita, Andriani, \& Trinanda, 2016). This research using primary data and the type of data in this research is likert scale. The technique of data collection to obtain the necessary data in this research used techniques of questionnaire, the method used for obtaining primary and secondary data (Trinanda, 2016).

The population in this research is all Padang city society who have read online reviews of Sirandah Island in the internet and have never visited Sirandah Island whose numbers are unknwon. The sample that will be use in this research are part of Padang city society who have read online reviews of Sirandah Island in the internet and have never visited Sirandah Island with inclusive criteria at least 18 years old and minimum education at least high school with the consideration of being able to understand and fill in the questionnaire well so that it is expected to obtain valid data (Wardi, Abror, \& Trinanda, 2018b). Data analysis was carried out using Structural Equation Model (SEM) using Partial Least Square (PLS) and smartPLS version 3.2.7 approaches as software. According to Hair, Black, Babin, Anderson, and Tatham (2010) the magnitude of the sample when too big will make it difficult to get a model that fits and advised the appropriate sample size between the 100-200 the respondent so that it can be used for estimation of interpretation with SEM. Determination of the minimum number of samples for SEM according to Hair et al. (2010) is: (5 multiplied by the maximum number of indicators of a latent variable).

On variable electronic word of mouth we used 6 indicator (Jalilvand et al., 2012), destination trust using 8 indicators (Abubakar \& Ilkan, 2016) and Revisit Intetion uses 3 indicators (Abubakar \& Ilkan, 2016). The total number of indicators used in this research is 17.Based on these guidelines, then the minimum number of samples for research are: Minimum sample = number of sample indicator $x 10=17 \times 10=170$ respondents calculation based on the above calculations, then the obtained sample size as much as 170 respondents that are the tourists have read online reviews of Sirandah Island in the internet and have never visited Sirandah Island. Sample size as much as 170 respondents considered can already represent the population so that 
the conclusions of the research of collection of data obtained through the sample can describe the characteristics of the population

\section{Results}

Here are the results of research on the characteristics of respondents in this research:

The majority of respondent are male, as many as $98(58 \%)$ of respondents and famale as many as $72(72 \%)$ of respondents.

Table 4. Characteristics of Respondents by gender

\begin{tabular}{|l|l|l|l|}
\hline Gender & $\begin{array}{l}\text { Total } \\
\text { Respondent }\end{array}$ & Percentage & Gender \\
\hline Male & Male & 98 & $58 \%$ \\
\hline Famale & Female & 72 & $42 \%$ \\
\hline
\end{tabular}

Source: Primer data, 2018

The majority of respodents are aged 18-25 years old, as many as $121(71 \%)$.

Table 5. Characteristics of respondents based on age

\begin{tabular}{|l|l|l|}
\hline Gender & $\begin{array}{l}\text { Total } \\
\text { Respondent }\end{array}$ & Percentage \\
\hline 18 s/d 25 years & 121 & $71 \%$ \\
\hline 26 s/d 30 years & 22 & $13 \%$ \\
\hline 31 s/d 35 years & 2 & $1 \%$ \\
\hline 36 s/d 40 years & 8 & $5 \%$ \\
\hline $\begin{array}{l}\text { More than 41 } \\
\text { years }\end{array}$ & 17 & $10 \%$ \\
\hline Total & 170 & $100 \%$ \\
\hline
\end{tabular}

Source: Primer data, 2018

The majority of respodents are occupationed student, as many as 90 (53\%).

Table 6. Characteristics of respondents based on occupation

\begin{tabular}{|l|l|l|}
\hline Occupation & \multicolumn{1}{|c|}{$\begin{array}{c}\text { Total } \\
\text { Respondent }\end{array}$} & $\begin{array}{c}\text { Percen } \\
\text { tage }\end{array}$ \\
\hline Student & 90 & $53 \%$ \\
\hline Government Employees & 24 & $14 \%$ \\
\hline Police/TNI & 4 & $2 \%$ \\
\hline Entrepreneur & 6 & $4 \%$ \\
\hline Private Employees & 13 & $8 \%$ \\
\hline Housewife & 0 & $0 \%$ \\
\hline Total & 170 & $100 \%$ \\
\hline
\end{tabular}

Source: Primer data, 2018

The majority of respodents are income less than Rp. 2.000.000, as many as 100 (59\%).

Table 7. Characteristics of respondents based on occupation

\begin{tabular}{|l|l|l|}
\hline Income & Total & Percentage \\
\hline
\end{tabular}


eCo-Buss

\begin{tabular}{|l|l|l|}
\hline & Respondent & \\
\hline Less than Rp. 2.000.000 & 100 & $59 \%$ \\
\hline $\begin{array}{l}\text { Rp. 2.000.000 - Rp. } \\
\text { 3.000.000 }\end{array}$ & 34 & $20 \%$ \\
\hline $\begin{array}{l}\text { Rp. 3.000.000 - Rp. } \\
\text { 4.000.000 }\end{array}$ & 15 & $9 \%$ \\
\hline $\begin{array}{l}\text { Rp. 4.000.000 - Rp. } \\
\text { 5.000.000 }\end{array}$ & 13 & $8 \%$ \\
\hline More than Rp. 5.000.000 & 8 & $5 \%$ \\
\hline Total & 170 & $100 \%$ \\
\hline
\end{tabular}

Source: Primer data, 2018

Descriptive Variable Statistics

Variable descriptive analysis in this research aims to provide a general description of the data collection that can be seen based on the mean (average) and standard deviation of each variable

Table 8. Results of criteria mean

Source: Primer data, 2018

\begin{tabular}{|l|l|l|}
\hline Variabel & Mean & STDEV \\
\hline $\begin{array}{l}\text { Electronic Word of } \\
\text { Mouth }\end{array}$ & 4,00 & 0,903 \\
\hline Destination Trust & 3,889 & 0,942 \\
\hline Travel Intention & 4,00 & 0,902 \\
\hline
\end{tabular}

Evaluation Outer Model

Convergent Validity

Convergent validity is determined using the loading factor/outer loading value parameter and the AVE (Average Variance Extract) value. Measurement can be categorized as habing good convergent validity if the value of outer loading > 0,6 (Hair et al., 2010). The following is a table value of loading factores from a total of 17 indicators contained in this research:

Table 9. Outer Loading

\begin{tabular}{|l|l|l|l|l|}
\hline Variable & No & Indicator & Outer loading $(>0.6)$ & Explanation \\
\hline \multirow{4}{*}{$\begin{array}{l}\text { Mouth } \\
\text { Mectronic Word of }\end{array}$} & 1 & EWOM1 & 0,756 & Valid \\
\cline { 2 - 5 } & 2 & EWOM 2 & 0,765 & Valid \\
\cline { 2 - 5 } & 3 & EWOM 3 & 0,810 & Valid \\
\cline { 2 - 5 } & 4 & EWOM 4 & 0,843 & Valid \\
\cline { 2 - 5 } & 5 & EWOM 5 & 0,819 & Valid \\
\cline { 2 - 5 } & 6 & EWOM 6 & 0,799 & Valid \\
\hline \multirow{5}{*}{ Destination Trust } & 7 & DT1 & 0,765 & Valid \\
\cline { 2 - 5 } & 8 & DT 2 & 0,820 & Valid \\
\cline { 2 - 5 } & 9 & DT 3 & 0,794 & Valid \\
\cline { 2 - 5 } & 0 & DT 4 & 0,809 & Valid \\
\cline { 2 - 5 } & 1 & DT 5 & 0,851 & Valid \\
\cline { 2 - 5 } & 2 & DT 6 & 0,735 & Valid \\
\cline { 2 - 5 } & 3 & DT 7 & 0,835 & Valid \\
\cline { 2 - 5 } & 4 & DT 8 & 0,805 & \\
\cline { 2 - 5 } & & & \\
\hline
\end{tabular}




\begin{tabular}{|l|l|l|l|l|}
\hline \multirow{3}{*}{ Travel Intention } & 5 & TI1 & 0,842 & Valid \\
\cline { 2 - 5 } & 6 & TI2 & 0,909 & Valid \\
\cline { 2 - 5 } & 7 & TI3 & 0,723 & Valid \\
\hline
\end{tabular}

Source: Primer data, 2018

Based on table 9, all the indicators or statement items are valid. According to (Hair et al., 2010), if there is a value outer loading below 0.6 in an indicator, then the indicator can be eleminated because it does not represent the existing construct. So that in this research there are no indicators that will removed or deleted.

Discriminant Validty

Testing of discriminant validty relates to the principle that every indicator contained in a different construct should not correlate with high (Hair et al., 2010).

Table 10. Discriminant validty

\begin{tabular}{|l|l|l|l|}
\hline Variabel & DT & EWOM & TI \\
\hline Destination Trust & $\mathbf{0 , 8 0 2}$ & & \\
\hline $\begin{array}{l}\text { Electronic Word of } \\
\text { Mouth }\end{array}$ & 0,686 & $\mathbf{0 , 7 9 9}$ & \\
\hline Travel Intention & 0,560 & 0,561 & $\mathbf{2 8}$ \\
\hline
\end{tabular}

Source: Primer data, 2018

Based on table 10, it can be concluded that the square root value of AVE is greater than other constructs. This shows that all construcs in the estimated researcr model meet the predetermined discriminant validity criteria.

Average Variance Extracted (AVE)

The measurement model of convergent validity is also seen from the AVE value. AVE value describes the magnitude of the diversity of the manifest/indicator variables contained in the construct. Based on Ghozali and Latan (2012), the use of AVE values is needed in converging validty testing. Furthermore, the recommended AVE values is at least 0.5 to indicate a good convergent validity.

Source: Primer data, 2018

Table 11. AVE (Average Variance Extrac|
\begin{tabular}{|l|l|}
\hline Variabel & $\begin{array}{l}\text { AVE } \\
(>0,5)\end{array}$ \\
\hline $\begin{array}{l}\text { Electronic Word of } \\
\text { Mouth }\end{array}$ & 0,639 \\
\hline Destination Trust & 0,644 \\
\hline Travel Intention & 0,686 \\
\hline
\end{tabular}

Based on the table 11, it appears that all variable have an AVE value that is greater than 0.5. it can be concluded that all variables in this research can explain an vaerage of more than half of the variants of each indicator that has good convergent validty.

Composite Reliability 
Composite reliability measures internal consistency and the value mus be abore 0.7 (Hair et al., 2010). The results of composite realibity can be seen in the table 11 .

Table 12. Composite Realiabity

\begin{tabular}{|l|l|l|}
\hline Variabel & $\begin{array}{l}\text { Composite Reliability (> } \\
0,7)\end{array}$ & Explanation \\
\hline $\begin{array}{l}\text { Electronic Word of } \\
\text { Mouth }\end{array}$ & 0,914 & Reliabel \\
\hline Destination Trust & 0,935 & Reliabel \\
\hline Travel Intention & 0,867 & Reliabel \\
\hline
\end{tabular}

Source: Primer data, 2018

Based on table 12, it can be seen that each variable used in this research has a good composite reliabity value that is greater than 0.7 . Therefore, each variable in this research can be said to have fullfilled the requirements that have a level of reliability in accordance with predetermined requirements.

\section{Evaluasi Inner Model}

Inner model test or structural model test

This test is used to evaluate the relationship between latent conditions as hypothesized in the research, based on PLS ouput, obatanied as follows:

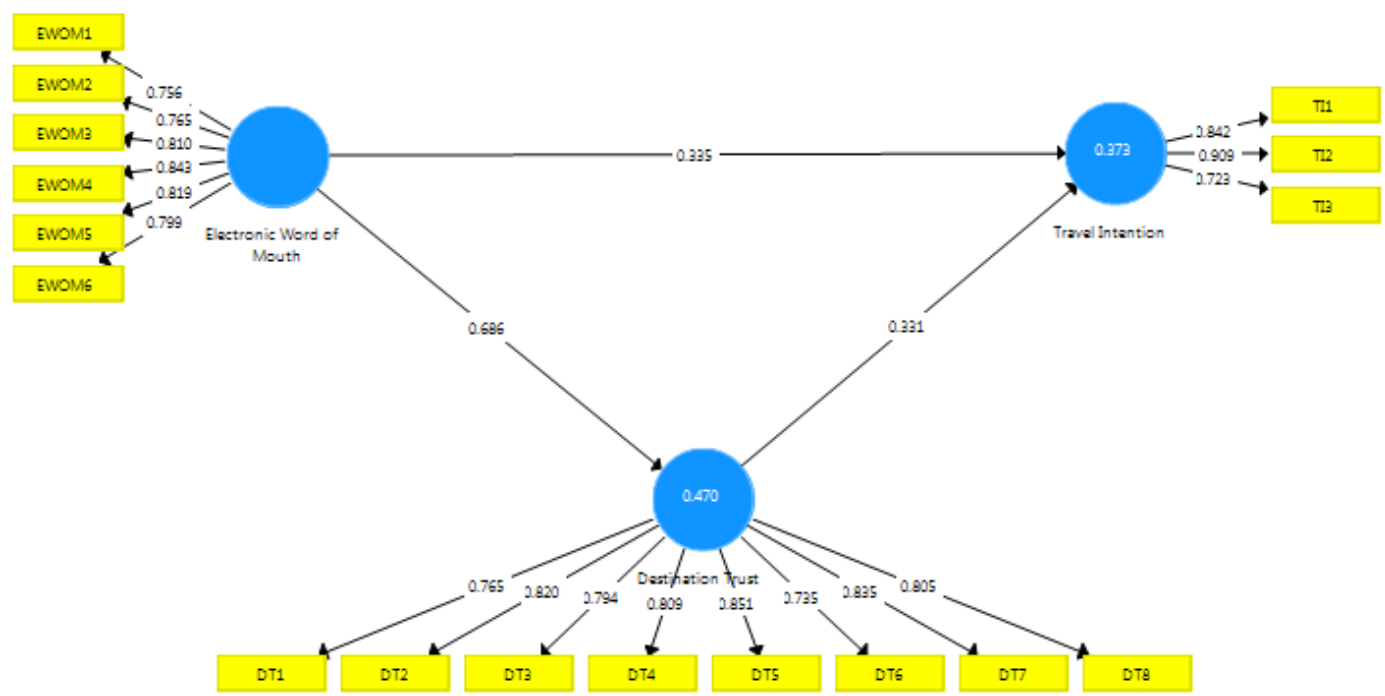

Figure 2. Path of all indicators

Source: Primer data, 2018

Hypothesis Testing

Table 13. Path Analysis

\begin{tabular}{|l|l|l|l|l|}
\hline & $\begin{array}{l}\text { Path } \\
\text { Coefficient }\end{array}$ & $\begin{array}{l}\text { T } \\
\text { Statistics }\end{array}$ & $\begin{array}{l}\text { P } \\
\text { Values }\end{array}$ & Explanation \\
\hline $\begin{array}{l}\text { Electronic Word of Mouth } \\
\text {-> Travel Intention }\end{array}$ & 0,335 & 5,177 & 0,000 & $\begin{array}{l}\text { H1 } \\
\text { supported }\end{array}$ \\
\hline
\end{tabular}




\begin{tabular}{|l|l|l|l|l|}
\hline $\begin{array}{l}\text { Electronic Word of Mouth } \\
\text {->Destination Trust }\end{array}$ & 0,686 & 12,312 & 0,000 & $\begin{array}{l}\mathrm{H} 2 \\
\text { supported }\end{array}$ \\
\hline $\begin{array}{l}\text { Destination Trust -> Travel } \\
\text { Intention }\end{array}$ & 0,335 & 3,335 & 0,001 & $\begin{array}{l}\mathrm{H} 3 \\
\text { supported }\end{array}$ \\
\hline
\end{tabular}

Source: Primer data, 2018

1. In this research it was found that the electronic word of mouth variable had a significant influenced on travel intention at Sirandah Island in Padang City, this research hypothesis can be accepted or proven and the findings support and strengthen the previous research.

2. In this research it was found that the electronic word of mouth variable had a significant influenced on destination trust at Sirandah Island in Padang City, this research hypothesis can be accepted or proven and the findings support and strengthen the previous research.

3. In this research it was found that the destination trust variable had a significant influenced on travel intention at Sirandah Island in Padang City, this research hypothesis can be accepted or proven and the findings support and strengthen the previous research.

\section{Structural Model Testing (Inner Model)}

Inner Model evaluation or strultural model aims to see the direct or indirect influence between variables. Evaluation on structural models can be strated by looking at the R-square value of the endogenous latent variables. According to Hair et al. (2010), R-square of 0.75, 0.5, 0.25 defined the model strongly, moderately, and weakly in explaining the effect of exogenous latent variables on endogenous latent variables.

Table 14. R-square Value

\begin{tabular}{|l|l|l|}
\hline Variable & $R$-Square & Explanation \\
\hline $\begin{array}{l}\text { Destination } \\
\text { Trust }\end{array}$ & 0,470 & Weakly \\
\hline Travel Intention & 0,373 & Weakly \\
\hline
\end{tabular}

Source: Primer data, 2018

Based on table 14 illustrates that the R-square value for destination trust variable is 0.470 , this indicates that the magnitude of the influence of electronic word of mouth variables weakly explains $47 \%$ of the destination trust variable while the remaining $53 \%$ is influenced by other factors. Furthermore, the R-square value for the travel intention variable is 0.373 , this indicates that the magnitude of the influence of electronic word of mouth variables and destination trust weakly explains $37,3 \%$ of the travel intention variable while the remaining $62,7 \%$ is influenced by other factors.

\section{Electronic Word of Mouth and Travel Intention}

Based on the result, we form that electronic word of mouth has a significant influenced on travel intention at Sirandah Island in Padang City. The results of this research in line with previous research that has done by Abubakar and Ilkan (2016) stated that positive's online reviews can increase tourists' travel intention. This research is also in line with research conducted by (Jalilvand et al., 2012) which revealed that the impact of electronic word of mouth on tourism destination choice is to help destination managers increase the tourists' travel intention

\section{Electronic Word-of-Mouth (E-WOM) and Destination Trust}

Based on the result, we form that electronic word of mouth has a significant influenced on destination trust at Sirandah Island in Padang City. The results of this research in line with 
previous research that has done by Abubakar and Ilkan (2016) stated that positive's online reviews can increase tourists' destination trust. This research is also in line with research conducted by Wardi et al. (2018a) revealed that electronic word of mouth has a significant influence on destination image and destination choice where the results provide a deeper and richer picture of the relationship between electronic word of mouth and destination trust.

\section{Destination Trust and Travel Intention}

Based on the result, we form that destination trust has a significant influenced on travel intention at Sirandah Island in Padang City. The results of this research in line with previous research that has done by (Abubakar \& Ilkan, 2016) stated that tourists' trust in tourism destinations can affect their travel intention.

\section{Conclusion}

1. According to the results obtained in this research, in general the Padang City society' travel intention towards Sirandah Island will be higher if this tourist attraction has positive electronic word of mouth. The more positive electronic word of mouth of Sirandah Island, it can increase the Padang City society' travel intention towards this tourist attraction. Conversely, if the tourist attraction of Sirandah Island does not have positive electronic word of mouth, it will cause the Padang City society' travel intention to become smaller.

2. Electronic word of mouth has a significant influenced on destination trust at Sirandah Island in Padang City. According to the results obtained in this research, in general the Padang City society' destination trust towards Sirandah Island will be higher if this tourist attraction has positive electronic word of mouth. The more positive electronic word of mouth on Sirandah Island, it can increase the Padang City society' destination trust towards this tourist attraction. Conversely, if the tourist attraction of Sirandah Island does not have positive electronic word of mouth, it will cause the Padang City society' destination trust to become smaller.

3. Destination trust has a significant influenced on travel intention at Sirandah Island in Padang City. According to the results obtained in this study, in general the Padang City society' travel intention towards Sirandah Island will be higher if they have a high destination trust on this tourist attraction. The more destination trust on Sirandah Island that felt by the Padang City society, it can increase their' travel intention toward this tourist attraction. Conversely, if the Padang City society dose not destination trust on Sirandah Island, it will cause their' travel intention to become smaller.

\section{References}

Ahmed, A. A., \& Hossain , M. S. (2010). Audit Report Lag: A Study of the Bangladeshi Listed Companies. ASA University Review, 49-56.

Angruningrum, S., \& Wirakusuma, M. G. (2013). Pengaruh Profitabilitas, Leverage, Kompleksitas Operasi, Reputasi KAP dan Komite Audit pada Audit Delay. E-Jurnal Akuntansi Universitas Udayana, 251-270.

Asthon, R. H., Willingham, J. J., \& Elliot, R. K. (1987). An Empirical Analysis of Audit Delay. Journal of Accounting Research, 275-292.

beritasatu. (2014, 4 15). Investor Daily - 49 Emiten Belum Serahkan Laporan Keuangan 2013. Diambil kembali dari www.beritasatu.com: www.beritasatu.com

Carslaw, C., \& Kaplan, S. (1991). An Examination of Audit. Accounting and Bussiness Research, 45-46.

Efendi, D., \& Utami, I. T. (2012). Faktor-faktor yang Mempengaruhi Audit Delay (Studi Empiris Perusahaan Manufaktur yang List di BEI). Ekonomika, 64-68. 
Febrianty. (2011). Faktor-Faktor Yang Berpengaruh Terhadap Audit Delay Perusahaan Sektor Perdagangan Yang Terdaftar di BEI Periode 2007-2009. Jurnal Ekonomi dan Informasi Akuntansi (Jenius), 294-320.

Halim, V. (2000). Faktor-faktor Yang Memperngaruhi Audit Delay. Jurnal Bisnis Akuntansi, 6375.

Handayani, A. P., \& Wirakusuma, M. G. (2013). Pengaruh Profitabilitas, Solvabilitas, Reputasi Kantor Akuntan Publik pada Ketidaktepatwaktuan Publikasi Laporan Keuangan Perusahaan di BEI. E-Jurnal Akuntansi, 472-488.

Harahap , S. S. (2007). Teori Akuntansi. Jakarta: PT. Rajagrafindo Persada.

Hersugondo, \& Kartika, A. (2013). Prediksi Probabilitas Audit delay dan Faktor Determinannya. Proceeding Fakultas Ekonomi Unisbank. UNISBANK.

Hugh, A. M., \& Dyers , J. (1975). The Timeliness of the Australian. Journal of Accounting Research, 204-219.

Indriyani, R. E., \& Supriyati. (2012). Faktor-faktor yang Mempengaruhi Audit Report Lag Perusahaan Manufaktur di Indonesia dan Malaysia. The Indonesian Accounting Review, $185-202$.

Kartika, A. (2009). Faktor-faktor yang Mempengaruhi Audit Delay di Indonesia (Studi Empiris pada Perusahaan-perusahaan LQ 45 yang Terdaftar di Bursa Efek Jakarta. Jurnal Bisnis dan Ekonomi (JBE), 1-17.

Lawrence, J., \& Glover, H. (1998). The Effect of Audit Firm Mergers on Audit Delay. Journal of Managerial, 151-165.

Lianto, N., \& Kusuma, B. H. (2010). Faktor-faktor yang Mempengaruhi Terhadap Audit Report Lag. Jurnal Bisnis dan Akuntansi, 97-106.

Subekti, I., \& Widiyanti, N. W. (2004). Faktor-faktor Yang Berpengaruh Terhadap Audit Delay di Indonesia. SNA VII Denpasar Bali, (hal. 991-1002). Denpasar. 